\title{
The Role of Value Innovation Capabilities in the Influence of Market Orientation and Social Capital to Improving the Performance of Central Kalimantan Bank in Indonesia
}

\author{
Usup Riassy Christa ${ }^{1, *}$, I Made Wardana ${ }^{2}$, Christantius Dwiatmadja ${ }^{3}$ and Vivy Kristinae ${ }^{1, *}$ (1) \\ 1 Faculty Economics and Business, Palangka Raya University, Jl. Hendrik Timang No. 17, \\ Palangka Raya-Kalimantan Tengah 73112, Indonesia \\ 2 Faculty Economics and Business, Udayana University, Jl. Sudirman, Denpasar-Bali 80631, Indonesia; \\ wardana@unud.ac.id \\ 3 Faculty Economics and Business, Satya Wacana Christian University, Jl. Diponegoro No 57, Salatiga, \\ Sidorejo-Jawa Tengah 50711, Indonesia; christantius.dwiatmadja@staff.uksw.edu \\ * Correspondence: usupriassy.christa@feb.upr.ac.id (U.R.C.); vivi.cristina@feb.upr.ac.id (V.K.)
}

Received: 15 October 2020; Accepted: 6 November 2020; Published: 11 November 2020

\begin{abstract}
Research in the field of banking business management during a pandemic requires the cooperation of organizations with the changing business environment. Resources that are able to be managed effectively and efficiently at the Central Kalimantan Regional Bank in Indonesia are thus managed in an effort to support the organization. The key to the bank's performance as an innovative organization lies in the core business values that are strengthened by organizational resources, so that the focus of value innovation becomes the activities that improve business performance as a mediating factor between external and internal factors. Research was conducted on 250 senior employees with quantitative analysis using the Structural Equation Modelling-Partial Least Square (SEM-PLS) statistical tool. It was found that external factors originating from market orientation and social capital significantly improved business performance. The success of the mediation process as a novelty research conceptual research has significant positive results as a core business innovation to improve the business performance of Central Kalimantan regional banks. The research objective is to improve banking performance by collaborating between consumer needs, value innovation and social capital as a trigger for excellent change in Bank Kal-Teng. The value of this research is as a reference for innovating capability value as the main business strategy using information from external factors, so as to improve the bank's business performance as needed.
\end{abstract}

Keywords: market orientation; social capital; value innovation capability; business performance

\section{Background}

The current era of globalization and pandemic is characterized by changes in the business environment that must be supported by rapid innovation and information in business strategies $[1,2]$. World bank business competition is increasingly competitive, and unpredictable turbulence has become a global issue, as a consequence of business performance [3,4]. This condition departs from various forms of business organization to change the paradigm of thinking and the way of doing business, from the traditional (classical) pattern, based on labor (labor-based business) which emphasizes the quantity of results (output, i.e., products/services), towards a business with modern business patterns [3-5], based on market orientation capabilities and social capital that depends on the quality of the results of a sustainable business. 
Management is the achievement of individual and organizational goals in performance, as an effective and efficient form of organization, in line with improving organizational performance [5]. The resource strategy formulation is carried out to achieve better business performance, and has strengths and weaknesses in human resources [6-8]. One form of strategy weakness is targeting a market against the background of consumer conditions and social capital to encourage the growth of the organization's vision and mission [7]. Efforts to achieve the organization's vision and mission based on the external environment are carried out as a control measure of the organization's business performance $[5,6]$.

Management that has a strategy based on POAC (planning, organizing, action, controlled) is an effective and efficient utilization and control of resource evaluation [8]. Business performance will have a high response, supported by workers who will actively change the market [8-10]. Thus, to achieve the performance measure, the organization must have the ability in market orientation [9]. The pandemic period has been a phenomenon for bank research in Central Kalimantan, because for seven months several bank products were affected; at this time, it cannot run according to the organization's vision and mission. One of the challenges for the community's economy is the sluggishness in purchasing banking products at Bank Kal-Teng, so it is necessary to evaluate improving business performance from a market orientation perspective.

Organizational performance that is able to synergize with environmental changes such as significant capital can improve business performance, as noted in several studies $[10,11]$. The phenomenon of obtaining profits based on interviews on products that ensure the safety and financial comfort of the public is the target of research [12]. The bank in Central Kalimantan is a Central Kalimantan regional-owned company with 14 branches as the focus of research. Based on preliminary research, long-term product interviews are less desirable, such as time deposits and education insurance [12-15]. Social capital is information, trust and norms attached to social networks $[13,15,16]$. Social capital as a resource embedded in social networks is accessed and used by actors to carry out certain actions; the interactions do not significantly improve business performance [14,17-20]. In this regard, social capital is prioritized to encourage activities that focus on bank products such as deposits, with the ability to reward innovations to improve business performance $[15-18,20]$. The purpose of this research is to improve bank performance based on external and core business factors on bank products that have an impact on the sustainability of banking $[16,19,21-25]$. The research implications would improve the bank's business performance, which is required before market orientation and social capital encourage innovation capability value so that bank products can again be in demand by people in Central Kalimantan.

The paper is composed of six chapters. The first chapter is an introduction to Section 1. The second is theory and hypotheses in Section 2. Section 3 is methodology and data. Section 4 is research results. Section 5 is a discussion. Finally, Section 6 is the conclusions and recommendations for the development of further research and research.

\section{Theory and Hypotheses}

This research assesses two aspects of management, namely human resources and marketing products. Therefore, this study applies the Resources Based View (RBV) theory as a grand theory to improve business performance based on the value innovation capability of market orientation and social capital $[7,9,13]$. Resources based on customer views, the existence of a business organization without customers/consumers, will never exist because customer satisfaction as the "core" of service business excellence is that the customer/customer is absolutely in a business transaction $[10,12,17]$. Thus, the service industry tries to attract customers, the banks operating in the Central Kalimantan region being no exception. The banking service industry business activities therefore need to investigate or prove empirically the extent to which the realization of market orientation, social capital, and innovation capability is of value [11-13]. 


\subsection{Business Performance}

Banking business performance is measured by overall profitability and liquidity by comparison of ratios and risks [1,6-9]. A more effective solvency ratio relative to the equity ratio is necessary to measure debt and equity that does not pass from one to the other, so that to manage bank performance requires market orientation capabilities. In addition, social capital has a need for a business context in the network relationship process to improve organizational performance. Business performance that supports social networks and social relationships can foster trust, support, and social relations; therefore, social capital is needed in organizations $[2,5,9,13,26]$.

Business performance achieved from the ability to value innovation in resource collaboration that is managed effectively and efficiently based on RBV theory is a good business strategy. To improve business performance, it is necessary to trust information, market orientation and social capital to drive the core business with the value of innovation [6,7,10-14]. Business performance can be achieved from collative action as a resource management strategy, developed as a group rather than through information needs. The need for relationship resources and social knowledge can be very powerful as a business foundation, causing a positive increase in business performance [8,13-17]. Thus, to improve the performance of the banking business, it is necessary to have the ability and expertise to manage access to resources and activities to establish some particular beneficial connections in relation to market orientation, social capital and value innovation capabilities $[9,10,15,27]$.

\subsection{Market Orientation}

Market orientation is the ability to analyze the market to drive innovation so that the organization can be sustainable and improve the market $[5-10,13]$. The benefit to the bank is a change in customer behavior; therefore, financial technology is needed as a strategy in orienting competitors for a collaboration platform to optimize performance. Market orientation is changing standards that intelligently creates interactive, more effective resources that drive organizational innovation $[7-9,16,17]$.

Market orientation is proactive knowledge oriented towards consumer and competitor needs, and interface coordination to drive organizational innovation. The fluctuation of changes in the business environment in the banking business requires knowledge of market orientation in encouraging value innovation for improved performance [6,7,9-11]. Growth and increase of profit increase the abilities of the bank, by reducing assets and comparing productivity and risk, to maximize the value of human resources and management. Financial ratios can be seen from the aspect of liquidity to be the ultimate target, so market orientation skills and intelligence capabilities are needed.

Capacity-building interventions in market orientation are relatively related to resource effectiveness in the resource-based theory view, to encourage value innovation capabilities which improve business performance [7-11,27-31]. Market orientation in practice can send information about consumer needs to create products that suit their needs. Business competition requires banking organizations to continue to innovate through value innovation in service companies to increase sales, growth and profits. Based on these empirical studies and theories, the research hypotheses are:

Hypothesis 1 (H1). Market orientation has a positive effect on business performance.

Hypothesis 2 (H2). Market orientation has a positive effect on value innovation capability.

\subsection{Social Capital}

The rise of a knowledge-based economy requires regulation due to the increasingly important role of social capital in an organization or company [14-16,32]. The important role of social capital is a determinant of sustainable business performance, because social capital is not only an intangible static asset, but also an ideological process and a tool to achieve banking goals, helping to create products that benefit consumers and organizations [33-37]. 
The demands of modern industrialization are characterized by the value that comes from intangible assets known as social capital, such as: knowledge and skills that are owned and inherent, the influence of society, the employee environment, relational networks, social networks and social norms, all of which enable employees to drive innovation and strategic change in order to encourage the creation of value innovation with the core aim of improving business performance [15,22-25,38-40].

The banking service industry business is one of the various types of service industries in Indonesia which operates in the financial services sector and is often referred to as a trust institution, in connection with the definition of a bank. A bank is a business entity that collects funds from the public in the form of savings and channels it in the form of credit or other forms in order to improve the standard of living of the people at large (Law no. 10 of 1998) [1,13,15-19]. The role of banking absolutely exists in a country, because the bank as a financial sector service industry plays an important role as a mobilizer for the national economy, which is one indication of the existence of a country. In order to improve the bank's business performance, expertise and resource capabilities through its employees seeing changes in the business environment from market orientation and social capital are required. Based on these empirical studies, the research hypotheses are:

Hypothesis 3 (H3). Social capital has a positive effect on business performance.

Hypothesis 4 (H4). Social capital has a positive effect on value innovation capability.

\subsection{Value Innovation Capability}

Value innovation capability (VIC) is considered a valuable asset for the company, to provide and maintain the added competitive product and for implementation of the overall strategy $[10,11,26,32,33,40,41]$. VIC can be a force in improving a business to live with core business values such as reward points in every transaction. The relationship innovation capability is the business ability to form, and the integration capabilities and resource capabilities to stimulate, innovation [5,10,17-22].

Customer social relations can be the scope of VIC for creative endeavors with blue ocean strategies, such as providing appropriate products/consolidation assistance to face the impact of a pandemic. The blue ocean strategy provides superiority to product-based activities with product attributes and product functionality in order to improve business performance [8,10,17-21]. Pandemic times require organizations to create different value products in the development of innovations that refer to knowledge of consumer segments and market segments to improve business performance [18,19,29-33,42].

The blue ocean strategy is applied in four ways by eliminating the core business that is not functioning optimally, reducing the system that cannot be developed in the community or with consumers $[17,21,37]$. Furthermore, it is important to improve synergies with maximum human resources, such as social capital simulations, to support core businesses and make high-value products that are minimized based on market orientation. Based on these the empirical study the research hypothesis theory proposed in this study is:

Hypothesis 5 (H5). Value innovation capability has a positive effect on business performance.

\subsection{Theoretical Framework}

The theoretical framework is made from empirical studies and research gap antecedents of market orientation and social capital with the aim of improving business performance $[5,8,13,27]$. Input is then made to build a conceptual framework into new research. Based on the RBV theory, the observation of business phenomena will be able to be the target of change, with policies received from external factors in building business strategies $[7,9,11,27,43]$. For this reason, this research proposes a framework with 
the ability to mediate value innovation to improve business performance. The input used to increase the output from previous research is based on the RBV theory, which aims to obtain applicable research results to improve the bank's business performance from external factors as potential information with reliable relevance. To facilitate the reference of results, a conceptual framework for the research based on the hypotheses was built as shown in Figure 1.

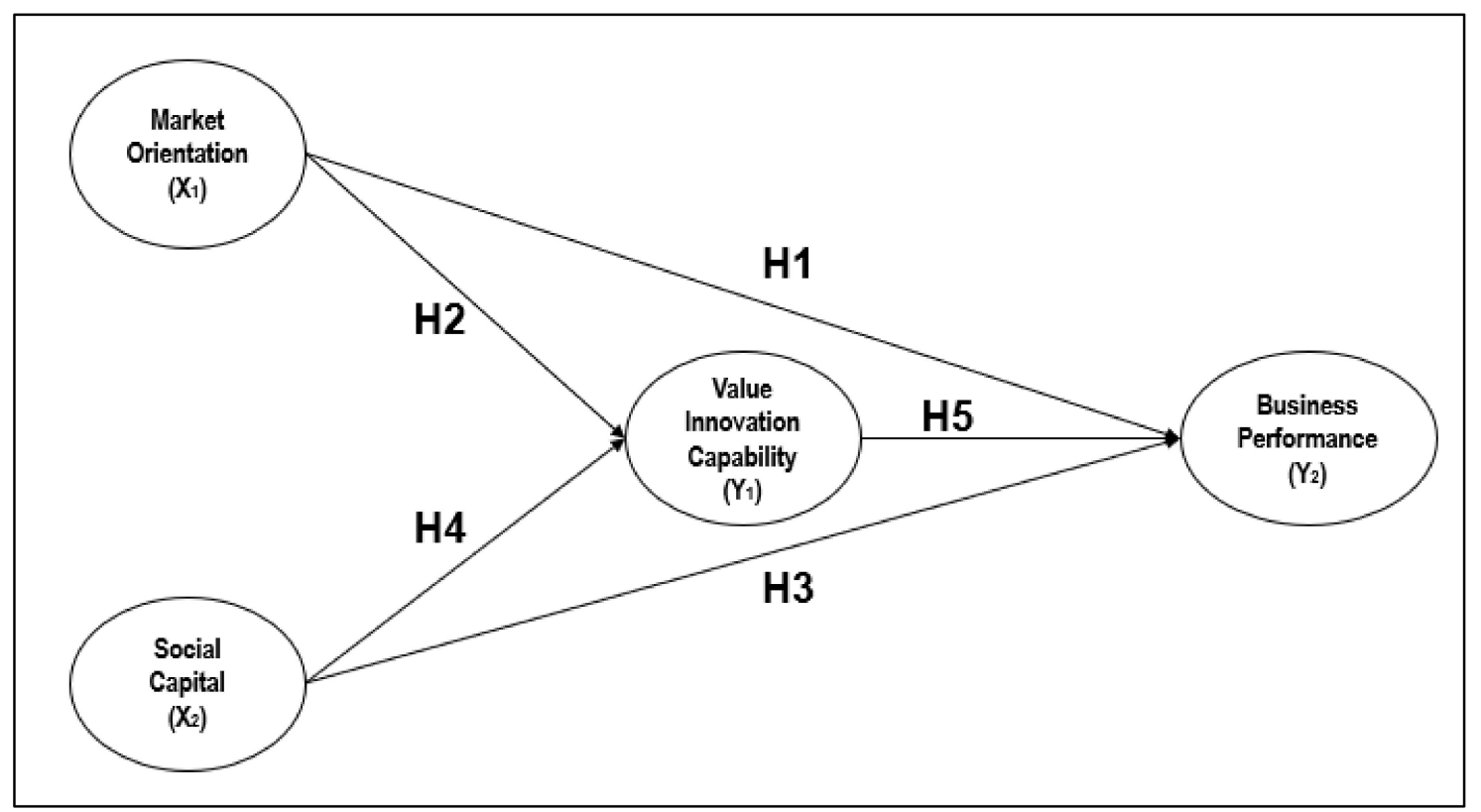

Figure 1. Concept framework, adoption of the model $[16,27,43]$.

\section{Methods}

The test was done quantitatively with the SEM-PLS statistical application. Respondents in this study were 250 employees with a questionnaire, according to the number of indicators from the four variables. The criteria for respondents were at least 5 years working at a Regional Bank in Central Kalimantan Province and have been in customer service before, so that the results of the questionnaire used in the study are not biased. The sample design was carried out randomly to maintain the quality of the results that refer to the previous theory and empirical studies so that the results can be trusted $[34,44]$. The research scale was a Likert scale, which is a survey scale for selecting approval (answers) to questions on the instrument ranging from 1 (strongly disagree) to 5 (strongly agree). The distribution of questionnaires was carried out with reference to the bank's business performance during the COVID-19 pandemic, through digital questionnaires. Questionnaire collection was subjective and received directly via email to the researcher. Before the questionnaire was distributed, the instrument was tested and evaluated on 30 respondents in order to obtain a good questionnaire instrument with validity and reliability tests $[18,23,34,44]$. Furthermore, distributing questionnaires to the sample was carried out using the SEM-PLS test to see the relationship between the influence of antecedents, mediation, exogenous variables and interpreting the research results clearly.

\section{Results}

Testing was based on a valid and reliable questionnaire instrument, so that the test results did not succumb to error/data bias. The mediating variable of the value innovation capability is a process in overcoming the research gaps from previous empirical studies. Based on the results, all variables have a correlation with business performance $\left(\mathrm{Y}_{2}\right)$. The results are presented in Figure 2, complete with probability values. 


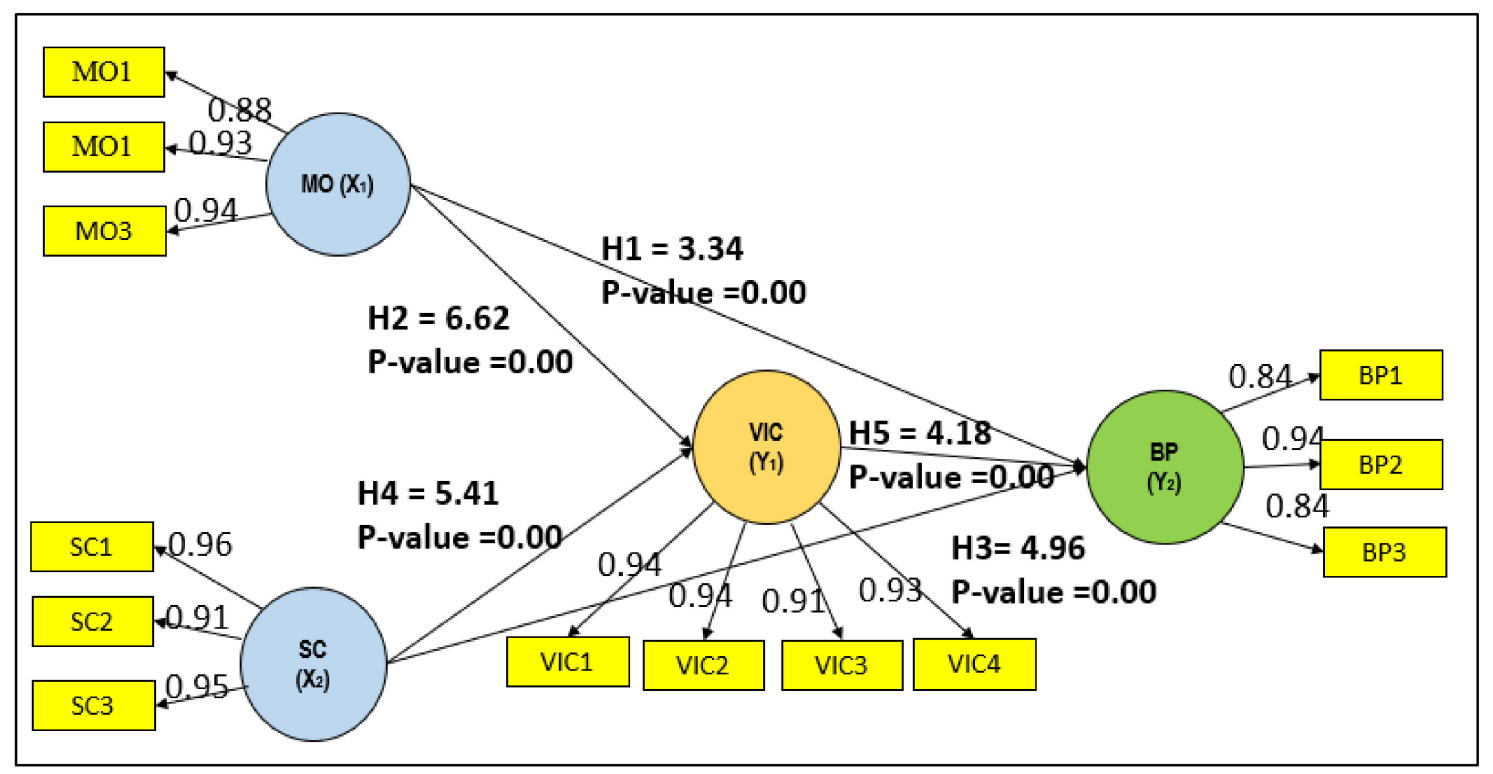

Figure 2. Results of the empirical research model. Source: author calculation.

In the partial least square (PLS) model, the loading factor for reflective indicators and for formative indicators is outer loading [24]. Based on the results, the outer loading of the indicators market orientation (MO), social capital (SC), value innovation capability (VIC) and business performance (BP) can be seen from Table 1, as follows:

Table 1. Outer loading.

\begin{tabular}{cccc}
\hline Variable & Indicators & Outer Loading & Mean \\
\hline \multirow{3}{*}{ Market Orientation $\left(\mathrm{X}_{1}\right)$} & Customer Orientation $\left(\mathrm{X}_{1.1}\right)$ & 0.880 & 3.36 \\
& Competitor Orientation $\left(\mathrm{X}_{1.2}\right)$ & 0.934 & 3.41 \\
& Interfirm Coordination $\left(\mathrm{X}_{1.3}\right)$ & 0.947 & 3.42 \\
\hline \multirow{3}{*}{ Social Capital $\left(\mathrm{X}_{2}\right)$} & Social Network $\left(\mathrm{X}_{2.1}\right)$ & 0.964 & 3.42 \\
& Relationship Network $\left(\mathrm{X}_{2.2}\right)$ & 0.914 & 3.43 \\
& Social Norms $\left(\mathrm{X}_{2.3}\right)$ & 0.954 & 3.41 \\
\hline \multirow{3}{*}{ Value Innovation Capability $\left(\mathrm{Y}_{1}\right)$} & Product Image Superiority $\left(\mathrm{Y}_{1.1}\right)$ & 0.940 & 3.41 \\
& Value Added Superiority $\left(\mathrm{Y}_{1.2}\right)$ & 0.944 & 3.42 \\
& Financial Secure Superiority $\left(\mathrm{Y}_{1.3}\right)$ & 0.916 & 3.41 \\
& Financial Guarantee Superiority $\left(\mathrm{Y}_{1.4}\right)$ & 0.937 & 3.42 \\
\hline \multirow{3}{*}{ Business Performance $\left(\mathrm{Y}_{2}\right)$} & Sales $\left(\mathrm{Y}_{2.1}\right)$ & 0.841 & 3.37 \\
& Growth $\left(\mathrm{Y}_{2.2}\right)$ & 0.944 & 3.41 \\
& Profit $\left(\mathrm{Y}_{2.3}\right)$ & 0.849 & 3.38 \\
\hline
\end{tabular}

Sources: Data processed by SEM-PLS, author calculation.

The indicator of market orientation is a characteristic of the outer loading variable with an average of $0.92>0.7$, and an average mean of 3.39, which means that it is a good category. Next, in the social capital of outer loading, the average is $0.944>0.7$, with an average mean of 3.42, which means it is a good category. For the outer loading innovation capability value variable, there is an average of $0.934>0.7$, with a mean of 3.41, which means it is a good category. Finally, the outer loading business performance variable has an average of $0.867>0.7$, with an average mean of 3.38 , which means it is a good category. A test was then carried out to get answers about the reliability of the following average variant extracted (AVE) values.

To see the average variant extracted (AVE) value in SEM-PLS, Table 2 shows the results that meet the requirements of the value above $>0.5$ for a good model; the results show that the MO variable is $0.82>0.5$, the SC variable is $0.87>0.5$, the VIC variable is $0.89>0.5$ and the $\mathrm{BP}$ variable is $0.76>$ 
0.5. The results show that each variable has good discriminant validity. To obtain reliable results from the research instrument, further test data was carried out; the results showed that each variable was reliable because the average was above $>0.6$. The Cronbach alpha value also meets the requirements of $>0.7$. Table 2 shows that all variables have a high level of reliability.

Table 2. Average variant extracted (AVE) Correlation and Score.

\begin{tabular}{cccccc}
\hline Variable & \multirow{2}{*}{ AVE $(>\mathbf{0 . 5})$} & \multicolumn{4}{c}{ Score Correlations on Variable (t-Statistic) } \\
\cline { 3 - 6 } & & $\mathbf{X}_{\mathbf{1}}$ & $\mathbf{X}_{\mathbf{2}}$ & $\mathbf{Y}_{\mathbf{1}}$ & $\mathbf{Y}_{\mathbf{2}}$ \\
\hline Market Orientation $\left(\mathrm{X}_{1}\right)$ & 0.823 & - & - & 0.662 & 0.334 \\
Social Capital $\left(\mathrm{X}_{2}\right)$ & 0.876 & - & - & 0.541 & 0.496 \\
Value Innovation & 0.893 & 0.662 & 0.541 & - & 0.418 \\
Capability $\left(\mathrm{Y}_{1}\right)$ & 0.761 & 0.334 & 0.496 & 0.418 & - \\
Business Performance $\left(\mathrm{Y}_{2}\right)$ & &
\end{tabular}

Sources: Data processed by SEM-PLS, author calculation.

The assessment of goodness of fit can be seen with the q-square value from Table 3. A q-square value has the same meaning as the coefficient determinant (r-square) in regression analysis, where the higher the q-square, the more the model can be said to be better. The results of the calculation of the q-square value are as follows:

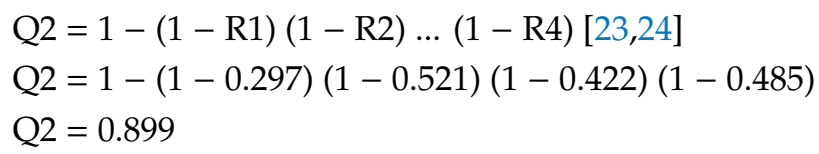

Table 3. Composite reliability and Cronbach's alpha.

\begin{tabular}{ccc}
\hline Variable & Composite Reliability (>0.6) & Cronbach's Alpha \\
\hline Market Orientation $\left(\mathrm{X}_{1}\right)$ & 0.862 & 0.877 (Reliability) \\
Social Capital $\left(\mathrm{X}_{2}\right)$ & 0.879 & 0.883 (Reliability) \\
Value Innovation Capability $\left(\mathrm{Y}_{1}\right)$ & 0.889 & 0.891 (Reliability) \\
Business Performance $\left(\mathrm{Y}_{2}\right)$ & 0.859 & 0.863 (Reliability) \\
\hline
\end{tabular}

Sources: Data processed by SEM-PLS, author calculation.

Based on the results of the above calculations, the q-square value is 0.899 . This shows the largest diversity of research data that can be trusted by the research model is $89.9 \%$ while the remaining $10.1 \%$ is factualized by other factors not examined in this study. Thus, this research model can be stated as having a good goodness of fit.

Based on Table 4, the description of the results shows that all variables in this model have a path coefficient with a positive $\mathrm{H} 1 \mathrm{t}$-statistic value of 0.334 and a $p$-value of $0.00<0.05$, which means market orientation has a significant positive effect on business performance and the hypothesis is accepted. For $\mathrm{H} 2$, the $\mathrm{t}$-statistic value is 0.662 and the $p$-value is $0.00<0.05$, meaning that social capital has a significant positive effect on the value of the ability to innovate and the hypothesis is accepted. The t-statistic value of $\mathrm{H} 3$ is 0.496 and the $p$-value is $0.00<0.05$, which means that social capital has a significant positive effect on business performance and the hypothesis is accepted. The t-statistic value of $\mathrm{H} 4$ is 0.541 and the $p$-value is $0.00<0.05$, which means that social capital has a significant positive effect on the value of innovation ability and the hypothesis is accepted. The t-statistic value of $\mathrm{H} 5$ is 0.418 and the $p$-value is $0.00<0.05$, meaning that innovation capability value has a significant positive effect on business performance and the hypothesis is accepted. 
Table 4. Hypothesis results.

\begin{tabular}{cccccc}
\hline \multicolumn{2}{c}{ Hypothesis } & R-Square & T-Statistics & $p$-Value & Results \\
\hline $\mathrm{H} 1$ & $\mathrm{BP} \leftarrow \mathrm{MO}$ & 0.297 & 0.334 & 0.004 & $\begin{array}{l}\text { Significant } \\
\text { (accepted) }\end{array}$ \\
$\mathrm{H} 2$ & $\mathrm{VIC} \leftarrow \mathrm{MO}$ & 0.521 & 0.662 & $0.000 *$ & $\begin{array}{l}\text { Significant } \\
\text { (accepted) }\end{array}$ \\
$\mathrm{H} 3$ & $\mathrm{BP} \leftarrow \mathrm{SC}$ & 0.422 & 0.496 & 0.001 & $\begin{array}{l}\text { Significant } \\
\text { (accepted) } \\
\text { Significant } \\
\text { (accepted) } \\
\text { Significant } \\
\text { (accepted) }\end{array}$ \\
\hline
\end{tabular}

* = very well less than zero. Sources: Data processed by SEM-PLS, author calculation.

\section{Discussion}

\subsection{Market Orientation Has a Positive Impact on Improving Business Performance}

Changes in the business environment from external factors greatly affect the effectiveness of market information. This can actively improve business performance; from the indicator of $33.4 \%$ with a $p$-value of $0.00<0.05$, market orientation is proven to have a significant positive effect. This is a good input with information, as the main intelligence to provide input that is relevant to customer needs is based on the results of the analysis through a questionnaire instrument that has AVE $>0.5$, and external loading and reliability $>0.6$. For the Central Kalimantan Regional Bank Business, the pandemic has become a problem. Performance is not well managed in terms of employees' ability to seek changing consumer needs and economies from market orientation. Collaboration between firms is carried out jointly in order to directly reach consumer needs and become a business strategy that can improve the bank's business performance.

Activities and processes related to customers in bank performance demand the ability of the organization to assess consumer needs well $[5,26,33,34,40,41,44]$. A pandemic period does not demand changes in business competition because of the economic downturn of society [27,41]. This makes market orientation very important in building business strategies to improve performance, not from a fully competitive orientation, but from what currently becomes a fundamental need for consumers, such as a trustworthy organization. In improving bank performance, the results of previous studies that were insignificant for external factors of $\mathrm{MO}$ to increase performance were rejected because the results showed that $\mathrm{MO}$ could be carried out/implemented by the organization properly to support performance based on market and consumer needs [16,17,41,45].

\subsection{Market Orientation Has a Positive Effect on Increasing the Value Innovation Capability}

Value innovation capability is a business strategy capable of completing a product in four stages, namely: reducing, eliminating, increasing and creating, better known as the blue ocean strategy [13,27]. The influence of consumer and market needs strongly affects activities in value innovation based on the results $(66.2 \%)$. This research proves that the higher the market orientation encourages the advantages of product image, the advantages of added value, the advantages of financial guarantees and the advantages of financial guarantees, the better VIC will be as the main point of business that is able to gain consumer benefits in choosing products at Bank Kalimantan Tengah in Indonesia. Based on these results, MO is a very good antecedent to encourage VIC [5,7-10,31]. This is a good input as the main intelligence to provide relevant input to customer needs based on the results of the analysis through a questionnaire has AVE $>0.5$, and outer loading and reliability $>0.6$. The better the innovation capability value supporting market orientation, the better the business strategy will be able to realize effective and efficient resources for the products offered by Bank Central Kalimantan in Indonesia. 
Efforts to improve the performance of banks with products have been greatly helped by the results based on market orientation $[5,38,42]$. The results also show that external factors can improve the bank's economy with several activities as cultural implementation $[3,30,46,47]$. The concept of market orientation makes the company/organization's goal to better understand consumer and market needs as a business strategy for good bank performance [12,42,48,49]. Therefore, new discoveries that are different in business strategy, by understanding and knowing consumer needs, are a good change for the performance of the Kal-Teng bank. The existence of an antecedent market orientation can encourage an organization's ability to innovate by implementing consumer and market needs. This encouragement will help companies increase value innovation activities to produce a management system based on the company's superior values $[18,45,48]$. In addition, this study states that market orientation is an input driving the value of innovation ability, which is very useful for business units to be able to survive following changes in the business environment.

\subsection{Social Capital Has a Positive Effect on Improving Business Performance}

When the quality of service performance is good, the bank's overall financial performance should also be good $[26,32,50]$. Through this series of processes, the bank will be able to create the best value, so that the bank's credibility will also be better, and so that the bank can be considered a trusted bank with excellent service $[33,40,41]$. "Trusted bank with excellent service" is the motto of commercial banks, reflecting the bank's competence in improving business performance as a core business strength. The above perspective implies that social networks, social norms and networks of relationships are very good links as external factors and are imperative for the banking service industry to be able to sustain business performance in a sustainable manner. Bank capital management functions as an integral unit to support external relations through optimization of roles to strengthen internal business performance [21-26,43].

The third component, social capital, must support each other or synergize in order to make a meaningful contribution to the company's goals, namely effective or sustainable performance. The results show that $49.6 \%$ of social capital improves marketing performance so that banks are able to mobilize and utilize social networks, social norms and relational networks to improve performance; good bank norms for customers are an external factor on the performance of services received. Efforts to maintain the performance of bank services in order to remain good from the perspective of external customers require high commitment from all lines of employees, and are carried out consistently [32,45]. If these efforts are made in the right situation, indicators of customer needs, networks and social norms are important points to gain trust and increase profitability in the banking business; if not the banking industry can face intense business environment changes from business competition, whether local, national and global.

\subsection{Social Capital Has a Positive Effect on Increasing the Value Innovation Capability}

Various national cases still frequently occur, such as the Century Bank case, ATM burglary, unclear information, customer complaints/dissatisfaction with bank services in print media, and word of mouth which is closely related to the operational/routine internal processes of the bank. This condition is a reflection of the condition of the bank's internal resources, where social capital has not been maximized as a business strategy to improve business performance [1-6,25,33]. To support input to output, business performance requires a superior business strategy, and the advantages of choosing products from value innovation to improve the performance of the Central Kalimantan banking business in Indonesia. Based on the results, social capital is able to encourage the ability to value innovation by $54.1 \%$, indicating that superior products from banks are difficult to accept by many consumers in markets that offer low prices and quality.

In terms of the products related to bank problems that occur in the banking service industry in Central Kalimantan, it seems that it is relatively the same as what happened to the banking service industry at the national level, but the scale is different. Changes in the national banking business 
that are increasingly competitive encourage and indicate the ability to innovate with values as a superior core business; thus, social networks, social norms and relationship networks are needed as the right solution to encourage business strategies at VIC which are able to solve problems in the operationalization of its business activities, in order to remain and survive in an uncertain business environment $[9,13,16,27]$. In line with economic growth, the need for banking services is getting higher, and the growth of the national banking service industry is increasing. The results show that social capital is significant in the value of innovation capability for the growth of the banking industry in the region, such as the performance of the banking business, especially in Central Kalimantan.

\subsection{The Value Innovation Capability Has a Positive Effect on Improving Business Performance}

The results of this study state that the value of innovation capability is a correct and positive process/mediation of $41.8 \%$ and a $p$-value of $0.00<0.05$, proving a significant positive effect on business performance. Furthermore, the results show evidence that VIC is capable of being a good and relevant mediation through a questionnaire instrument that has AVE $>0.5$ of outer loading and reliability $>0.6$ in improving the business performance of Central Kalimantan Bank in Indonesia. The value innovation capability is an innovation activity that is carried out based on a business strategy to increase revenue and sales by creating a value curve that stands out as the core of the business [14,22,26,32]. Marketing performance measurement can be seen from product improvement and sales increase; in innovation activities, the value of product superiority and product function is a superior value for a strong core business. Meanwhile, marketing performance is the result achieved by business units from activities in the field of effective and efficient marketing, through managing resources by implementing business strategies $[5,17,27,38,39,46,51]$.

The results of this study can provide evidence for the management of Bank Kalimantan Tengah in Indonesia, that to improve business performance requires value innovation capabilities based on the ability of employees to evaluate the products offered to suit the needs of consumers and social capital. In addition, the value innovation capability that is driven by employee relations from social capital will be able to create relationships, norms and networks that support business performance from VIC mediation. This has implications and benefits for improving business performance that requires market orientation capabilities. Social capital as an external analyst related to changes in the business environment is able to encourage the mediation of value innovation capability as a business strategy to take actions and to improve the business performance of Bank Kalimantan Tengah in Indonesia.

\subsection{Market Orientation, Social Capital and Value Innovation the Improving Performance Bank}

Market orientation is a measure of external factors that require products or services in the banking business. Activities that are in a market orientation are related to meeting customer needs and related to creating confidence in bank performance $[5,10,13,40]$. To get a lot of customers, an organization needs knowledge and abilities based on market orientation from customer orientation, competitor orientation and coordination between functions [13,14,19-21]. The results of this study state that it is positive and significant that external factors of customers and market needs have a very good effect on improving the performance of the banking business in Kal-Teng in Indonesia. This becomes a reference to the bank's business strategy method, which has the potential to increase bank sales, growth and profits $[26,27,34-37,40,44,48]$.

Social capital based on social networks in society is changes during pandemic. Social capital has three main pillars, namely social networks, relationship networks and social norms [2,3,19]. The relationship between these external factors is necessary to implement business strategies in making new policies related to changes in society $[26,44]$. Value innovation is one of the dynamics of innovation that is very sensitive to core business values, which are based on the values of product excellence. To encourage value innovation, external factors are needed, such as market orientation based on needs and social capital based on network values, network relationships and different superior cultures that have the potential to improve bank performance $[9,16,25,38,39,46,51]$. The results of social capital 
research can improve the performance of the Kal-Teng bank because the factors of social value, network value and network relationships can encourage value innovation capability to create a business strategy that is superior to the core value of the bank's product business.

Value innovation capability is a renewal based on core business values from cultural dynamics that come from people from generation to generation using regional bank products $[5,10,13,24]$. People's trust diminishes with the changing times, so that to maintain the core of the business, an internalization process is needed in open innovation for business patterns and actions $[9,17,43]$. Some changes that can be made are knowledge of the needs and social capital of the community as well as their economic conditions, so that the core business in value innovation capability continues to shine in the midst of a pandemic through the evolution of product loyalty [27,42]. The results of market orientation research and social capital can encourage the value of innovation capability with indicators of product image advantages, added value advantages, financial security advantages and financial security advantages $[17,26,27,34-36,40,41,44]$. This provides a reference for banks that wish to improve the bank's business performance by collaborating with external and core business factors on innovation so that system updates, methods and bank products can be accepted by the public because of their superior business value.

\section{Conclusions and Recommendations}

Tight business competition and changes in business related to current national economic conditions seem to have led to a better direction; however, the impact of the pandemic over the past eight months has been a multidimensional crisis that could improve business performance. It seems that the national banking business is still unable to create a real financial sector; it is at present still stagnant, inflation is still high, credit distribution is still not as expected and the allocation of the amount of credit extended to the public is still in the range of 30-35\%, far from the ideal range set at $90-95 \%$ (Bank Indonesia, 2008) $[26,32,33,40,41]$. This condition also applies and has an impact on the decline in the value of the fostered units because public trust in savings funds in national banks has decreased. This research is aimed at Central Kalimantan banks so that people continue to trust regional banks as future relations, guaranteeing deposits and insurance, which have a good impact on sales, growth and sustainable profit performance of banks.

In this study, business banking can be improved from external factors, namely the community as customers. In order for national banking in the country to have credibility, it requires knowledge and capability of market orientation and social capital. Thus, changes in the business environment related to customer needs and the relationships inherent in social capital can be an input to encourage product excellence that is highlighted as the core of a fundamental business strategy through value innovation capabilities. This is very necessary for the realization of a good banking system, and is included in the category of domestic banks that can be trusted by the public for good and reliable public financial guarantees. This research can be a resource-based strategic management research development that must be managed properly and continuously to improve business performance, as well as provide opportunities for other research to apply RBV theory and variable value innovation capabilities as business strategies in other business units in Indonesia. The limitation of this research is that it was carried out during a pandemic where the results of the research may not be fully answered by the sample in a professional manner; therefore, in future studies a qualitative or mixed test method is recommended, to get better results in improving bank business performance by appreciating innovation in other provinces and countries.

Author Contributions: Conceptualization, phenomenon research, analysis of formats, resources, visualization, U.R.C., I.M.W., C.D., V.K.; format analysis, investigation, visualization, gap analysis, resources, I.M.W., V.K.; methodology, theory, mediating variables, data curation, C.D. and U.R.C.; supervision, writing, reviews, questionnaires, mind mapping research, data analysis, editing, V.K. and I.M.W. All authors have read and agreed to the published version of the manuscript.

Funding: This study received no external funding. 
Acknowledgments: We would like to thank the Central Kalimantan Bank in Indonesia for the collaboration and data that was provided openly to the authors to enrich knowledge in management as well as a reference for research sites to improve performance by implementing strategies.

Conflicts of Interest: The authors state there is no conflict of interest.

\section{References}

1. Abdelhalim, A.-Z.B. The direct and indirect influences of locus of control on Jordanian parents' communication patterns: Consumer socialization and cultural perspectives. J. Islamic Mark. 2016, 7, 167-186. [CrossRef]

2. Edwards, D.B. Shifting the perspective on community-based management of education: From systems theory to social capital and community empowerment. Int. J. Educ. Dev. 2019, 64, 17-26. [CrossRef]

3. Sutrisno, T.; Saraswati, E.; Purnomosidhi, B. The effect of related party transactions on firm performance: The moderating role of political connection in indonesian banking. Bus. Theory Pract. 2019, 20, 81-92. [CrossRef]

4. Beverland, M.B. Unpacking value creation and delivery: Orientation, capabilities, practices, and outcomes. Ind. Mark. Manag. 2012, 41, 8-10. [CrossRef]

5. Kristinae, V.; Sambung, R.; Sahay, M. The Role of Entrepreneurial Orientation in Product Innovation in Emerging Markets on The Local Products. Oradea J. Bus. Econ. 2019, 4, 35-44. [CrossRef]

6. Augusto, M.; Torres, P. Effects of brand attitude and eWOM on consumers' willingness to pay in the banking industry: Mediating role of consumer-brand identification and brand equity. J. Retail. Consum. Serv. 2018, 42, 1-10. [CrossRef]

7. Halawi, L.A.; Aronson, J.E.; McCarthy, R.V. Resource-Based View of Knowledge Management for Competitive Advantage. Electron. J. Knowl. Manag. 2005, 3, 75-86.

8. Chang, C.-H. Do green motives influence green product innovation? The mediating role of green value co-creation. Corp. Soc. Responsib. Environ. Manag. 2019, 26, 330-340. [CrossRef]

9. Limakrisna, N.; Yoserizal, S. Determinants of marketing performance: Empirical study at National Commercial Bank in Jakarta Indonesia. Springerplus 2016, 5, 1693. [CrossRef]

10. Dharma, Y. The effect of work motivation on the employee performance with organization citizenship behavior as intervening variable at Bank Aceh Syariah. In Proceedings of the MICoMS 2017, Lhokseumawe, Indonesia, 26-28 November 2017; Emerald Publishing Limited: Bingley, UK, 2018.

11. Fauzan, M.O.; Yuniarsih, T.; Santoso, B. Subjective Well-Being: A Case Study on Outsourcing Workers of Pt Bank Rakyat Indonesia Office of the Jambi Province Branch Coordinator. 2020. Available online: https://www.semanticscholar.org/paper/Subjective-Well-Being\%3A-A-Case-Study-On-OutsourcingFauzan-Disman/782361758ea73cb7af73544f7a4fb30b240866e5 (accessed on 4 May 2020).

12. Pravitasari, A.E.; Rustiadi, E.; Mulya, S.P.; Fuadina, L.N. Developing regional sustainability index as a new approach for evaluating sustainability performance in Indonesia. Environ. Ecol. Res. 2018, 6, 157-168. [CrossRef]

13. Nahan, N.; Kristinae, V.; Leiden, R.A.Z. The Strength of a Business Strategy with Value Innovation for Rattan Handicraft Entrepreneurs in Central Kalimantan, Indonesia. Int. J. Bus. Manag. 2019, 7. [CrossRef]

14. Teece, D.J. Business Models, Business Strategy and Innovation. Long Range Plan. 2010, 43, 172-194. [CrossRef]

15. Abdelsalam, O.; Dimitropoulos, P.; Elnahass, M.; Leventis, S. Earnings management behaviors under different monitoring mechanisms: The case of Islamic and conventional banks. J. Econ. Behav. Organ. 2016, 132, 155-173. [CrossRef]

16. Kajalo, S.; Lindblom, A. Market orientation, entrepreneurial orientation and business performance among small retailers. Int. J. Retail. Distrib. Manag. 2015, 43, 580-596. [CrossRef]

17. García-Villaverde, P.M.; Rodrigo-Alarcón, J.; Ruiz-Ortega, M.J.; Parra-Requena, G. The role of knowledge absorptive capacity on the relationship between cognitive social capital and entrepreneurial orientation. J. Knowl. Manag. 2018. [CrossRef]

18. Saerang, D.P.; Tulung, J.E.; Ogi, I. The influence of executives' characteristics on bank performance: The case of emerging market. J. Gov. Regul. 2018, 7. [CrossRef]

19. Soewarno, N.; Tjahjadi, B. Measures that matter: An empirical investigation of intellectual capital and financial performance of banking firms in Indonesia. J. Intellect. Cap. 2020. [CrossRef]

20. Iramani, R.R.; Muazaroh, M.; Mongid, A. Positive contribution of the good corporate governance rating to stability and performance: Evidence from Indonesia. Probl. Perspect. Manag. 2018, 16, 1-11. [CrossRef] 
21. Zulaikah, S.; Larasati, D.A.; Harymawan, I. Government ownership, human resources disclosure, and firm performance: Evidence from the banking industry in Indonesia. Int. J. Innov. Creat. Chang. 2019, 9, 238-264.

22. Bijoylaxmi, S.; Zillur, R.; Shampy, K. Customer co-creation and adoption intention towards newly developed services: An empirical study. Int. J. Cult. Tour. Hosp. Res. 2017, 11, 372-391. [CrossRef]

23. Suseno, Y. Disruptive innovation and the creation of social capital in Indonesia's urban communities. Asia Pac. Bus. Rev. 2018, 24, 174-195. [CrossRef]

24. Febrian, A.F.; Maulina, E.; Purnomo, M. The influence of social capital and financial capability on sustainable competitive advantage through entrepreneurial orientation: Empirical evidence from Small and Medium Industries in Indonesia using PLS-SEM. Adv. Soc. Sci. Res. J. 2018, 5. [CrossRef]

25. A Kadim, K.; Nardi, S.; Hendro, W.; Dessy, A.; Endang, K. The Effects of Bank Soundness with The RGEC Approach (Risk Profile, Good Corporate Governance, Earnings, Capital) Of Leverage And Its Implications On Company's Value Of State Bank In Indonesia For The Period Of 2012-2016. IJER Int. J. Econ. Res. 2018, 15, 41-52.

26. Maghfuriyah, A.; Azam, S.; Shukri, S. Market structure and Islamic banking performance in Indonesia: An error correction model. Manag. Sci. Lett. 2019, 9, 1407-1418. [CrossRef]

27. Kristinae, V.; Wardana, I.; Giantari, I.G.K.; Rahyuda, A.G. The role of powerful business strategy on value innovation capabilities to improve marketing performance during the COVID-19 pandemic. Uncertain Supply Chain Manag. 2020, 8, 675-684. [CrossRef]

28. Chen, A.; Peng, N.; Hung, K.-P. Managing salespeople strategically when promoting new products-Incorporating market orientation into a sales management control framework. Ind. Mark. Manag. 2015, 51, 141-149. [CrossRef]

29. Alford, P.; Duan, Y. Understanding collaborative innovation from a dynamic capabilities perspective. Int. J. Contemp. Hosp. Manag. 2018, 30, 2396-2416. [CrossRef]

30. Cambra-Fierro, J.; Pérez, L.; Grott, E. Towards a co-creation framework in the retail banking services industry: Do demographics influence? J. Retail. Consum. Serv. 2017, 34, 219-228. [CrossRef]

31. Zehir, C.; Yıldız, H.; Köle, M.; Başar, D. Superior Organizational Performance through SHRM Implications, Mediating Effect of Management Capability: An Implementation on Islamic Banking. Procedia Soc. Behav. Sci. 2016, 235, 807-816. [CrossRef]

32. Christa, U. Pengaruh Human Capital, Structural Capital, Relational Capital Terhadap Kinerja Layanan Bank dan Kepuasan Pelanggan. (Studi pada Industri Jasa Bank Umum di Kalteng). Ph.D. Thesis, Universitas Brawijaya, Malang, Indonesia, 2011.

33. Hidayat, N.; Lee, C.W. The effect of knowledge sharing on the service innovation performance: An empirical study on restaurant in North Kalimantan, Indonesia. J. Metris 2018, 19, 31-36.

34. Hair, J.F.; Ringle, C.M.; Sarstedt, M. PLS-SEM: Indeed a Silver Bullet. J. Mark. Theory Pract. 2011, 19, $139-152$. [CrossRef]

35. Sutarlan, S. Innovation and market orientation model in improving the performance of BRI. J. Res. Mark. 2018, 8, 698-706. [CrossRef]

36. Pranajaya, A.; Rini, E.S.; Sadalia, I. The Determinants of the Business Performance of Bank Muamalat Indonesia in the Sumatera Utara Business Region. In Proceedings of the 2019 International Conference on Organizational Innovation (ICOI 19), Ulsan, Korea, 20-22 July 2019; Atlantis Press: Paris, France, 2019.

37. Sudarmadji, C.F.; Sidharta, H.; Wiryakusuma, I.G.B.Y. The Effect of Entrepreneurship Orientation and Market Orientation on Marketing Performance of Furniture Home Industry in Sawahan District. Rev. Manag. Entrep. 2020, 4, 95-116.

38. Ievdokymov, V.; Lehenchuk, S.; Zakharov, D.; Andrusiv, U.; Usatenko, O.; Kovalenko, L. Social capital measurement based on "The value explorer" method. Manag. Sci. Lett. 2020, 10, 1161-1168. [CrossRef]

39. Mercado, M.D.P.S.R.; Vargas-Hernández, J.G. Analysis of the Determinants of Social Capital in Organizations. Bus. Ethics Leadersh. 2019, 3, 124-133. [CrossRef]

40. Bimaria, O. Pengaruh Kompetensi Terhadap Kinerja Pegawai Kantor Perwakilan Bank Indonesia Provinsi Kalimantan Tengah. Ph.D. Thesis, STIE Indonesia Banjarmasin, Banjarmasin, Indonesia, 2016.

41. Rusydiana, A.S.; Sanrego, Y.D. Measuring the performance of Islamic banking in Indonesia: An application of Maslahah-efficiency quadrant (MEQ). J. Islamic Monet. Econ. Financ. 2018, 3, 79-98. [CrossRef] 
42. Apparao, D.; Garnevska, E.; Shadbolt, N. Examining commitment, heterogeneity and social capital within the membership base of agricultural co-operatives-A conceptual framework. J. Co-Oper. Organ. Manag. 2019, 7, 42-50. [CrossRef]

43. Farida, N. Antecedent of Innovation and Marketing Performance in Batik Industry. Adv. Sci. Lett. 2017, 23, 471-474. [CrossRef]

44. Hair, J.F.; Black, W.C.; Babin, B.J.; Anderson, R.E. Multivariate Data Analysis; Prentice Hall: Upper Saddle River, NJ, USA, 2010.

45. Pahlevi, C.; Ruslan, A. Effect of Market Structure and Financial Characteristics on Bank Performance in Indonesia. Int. J. Acad. Res. Account. Financ. Manag. Sci. 2019, 9, 128-139.

46. Manning, P.C. Managing Social Capital? The Relational Dimension. In The Human Factor in Social Capital Management: The Owner-Manager Perspective; Emerald Group Publishing Limited: Bingley, UK, 2015; Volume 9, pp. 149-185.

47. Rizki, M.; Parashakti, R.D.; Saragih, L. The effect of transformational leadership and organizational culture towards employees' innovative behaviour and performance. Int. J. Econ. Bus. Adm. 2019, 7, 227-239. [CrossRef]

48. Alhabsji, T.; Suharyono, M.A.; Zaiunul Arifin, M.S. Effect of Market Orientation on Learning Orientation to Reach Competitive Advantage Rural Credit Banks in East Java Province-Indonesia. Int. J. Innov. Sci. Res. Technol. 2020, 5, 629-640.

49. Iman, N. Traditional banks against fintech startups: A field investigation of a regional bank in Indonesia. Banks Bank Syst. 2019, 14, 20-33. [CrossRef]

50. Selviasari, R. Effect of situational leadership style, compensation and motivation on employee performance in pt. Bank rakyat Indonesia (persero), tbk. Kediri branch. J. Eng. Manag. Ind. Syst. 2019, 7, 40-52. [CrossRef]

51. Wang, C.; Steiner, B. Can social capital explain business performance in Denmark? Empir. Econ. 2019, 59, 1699-1722. [CrossRef]

Publisher's Note: MDPI stays neutral with regard to jurisdictional claims in published maps and institutional affiliations.

(C) 2020 by the authors. Licensee MDPI, Basel, Switzerland. This article is an open access article distributed under the terms and conditions of the Creative Commons Attribution (CC BY) license (http://creativecommons.org/licenses/by/4.0/). 